\title{
The rationale for druggability of CCDC6- tyrosine kinase fusions in lung cancer
}

\author{
Aniello Cerrato ${ }^{*}$, Roberta Visconti and Angela Celetti ${ }^{*}$ (D)
}

\begin{abstract}
Gene fusions occur in up to $17 \%$ of solid tumours. Oncogenic kinases are often involved in such fusions. In lung cancer, almost $30 \%$ of patients carrying an activated oncogene show the fusion of a tyrosine kinase to an heterologous gene. Several genes are partner in the fusion with the three kinases ALK, ROS1 and RET in lung. The impaired function of the partner gene, in combination with the activation of the kinase, may alter the cell signaling and promote the cancer cell addiction to the oncogene. Moreover, the gene that is partner in the fusion to the kinase may affect the response to therapeutics and/or promote resistance in the cancer cells. Few genes are recurrent partners in tyrosine kinase fusions in lung cancer, including CCDC6, a recurrent partner in ROS1 and RET fusions, that can be selected as possible target for new strategies of combined therapy including TKi.
\end{abstract}

\section{TK fusions and their targeting in cancer}

Structural chromosome rearrangements are frequent events in solid tumours and result in gene fusions, which can be diagnostic and prognostic for a selected tumour type. Current evidences indicate that the protein products of these fusions lead to a state of oncogene addiction, implying that they are ideal targets of anticancer drugs.

The list of known oncogenic fusions continues to grow with the improving of the detection methods, resulting to date in the identification of at least one gene fusion in up to $17 \%$ of solid tumours $[1,2]$. Moreover, technical advances have simplified the detection of the gene fusions and in many cases they are now routinely searched for a more precise diagnosis and a more effective treatment of cancer patients.

One partner in such fusions is often an oncogenic tyrosine kinase (TK) that ends up to being constitutively active and with augmented, deregulated downstream signalling [3]. In most of the cases the heterologous gene fused to the kinase contributes the structural domains, which favour dimerization, trans-phosphorylation and constitutive activation of the kinase itself. However, upon the gene fusion, the active state of the kinase is promoted also by additional mechanisms, such as increased expression, altered turnover, conformational

\footnotetext{
*Correspondence: a.cerrato@ieos.cnr.it; celetti@unina.it

Institute for the Experimental Endocrinology and Oncology "Gaetano

Salvatore", Italian National Council of Research, Via S. Pansini 5, 80131 Naples, Italy
}

modifications, loss of the autoinhibitory domains and change of the substrates $[1,4-10]$.

Interestingly, the tyrosine kinase fusions to other genes also cause the inactivation of the heterologous partner gene as effect of its truncation, deletion or separation from its promoter [11]. Thus, independently from the activation of the kinase, the partner gene modifications might also provide additional effects on cellular signalling and gene transcription, including the activation of different pathways and chromatin remodelling [12]. Of note, in some cases, the gene that is partner in fusion with the TK might contribute, at least in part, to the ogenic addiction and full cell transformation. Thus, erent partner genes can differently affect tumour proession and response to therapeutics, including acquisi-

Tyrosine kinases are sensitive to different inhibitors (TKIs), generally classified in five types, depending on their mechanisms of action. Type I and II inhibitors occupy the adenosine trisphosphate (ATP)-binding pocket in both the active and inactive conformations of the kinase; type III and IV, by binding next to the ATP-binding site or outside of the cleft, act as allosteric inhibitors. Finally, type $\mathrm{V}$ inhibitors are referred as bivalent because they target simultaneously two distinct region of the protein kinase. Anyway, the majority of small molecules inhibit multiple kinases because the ATP-binding sites are highly conserved, leading to 'off-target' effects [13]. 
As kinases are ideal targets for therapy, several inhibitors are routinely used in the treatment of cancers harbouring TK activation, independently from the fact that its activation occurred upon point mutation or gene fusion. Unfortunately, the predicted efficacy of tyrosine kinase inhibitors based on biochemical, preclinical evidences obtained in vitro and in vivo, is not always confirmed in the clinic [14]. This divergence could be also ascribed to the fact that current TK inhibitors are more effective in patients harbouring TK point mutations than in patients carrying fusions of the same kinase [15]; thus, the need to deeply investigate the clinical impact of TK mutations versus TK fusion isoforms for their targeting. Owing to the low prevalence of the described molecular alterations, it is often impractical to clinically test the selected inhibitors in typical phase I/II trials, which only include patients with tumours of similar histology. Basket trials that involve patients with specific driver molecular alterations, regardless of the tumour histology, are therefore likely to provide more reliable results. Moreover, in the case of TK fusions, basket trials could also make possible to investigate the role of the different partner genes in the overall mechanisms of drugs sensitivity and/or resistance to TK inhibition, contributing additional clues for new strategies of combined therapy [16].

In this review we provide a speculative analysis of TK fusions, focusing on the paradigm of lung cancer, in order to supply useful information on drugs and drug cocktails that attack the unique networks activated by the fusions of the tyrosine kinases anaplastic lymphoma kinase (ALK), v-ros avian UR2 sarcoma virus oncogene homolog 1 (ROS1) and rearranged during transfection (RET), overall occurring in 5-10\% of lung cancer. While this prevalence may seem low at first glance, the high incidence of lung cancer cases in the United States means that about 10,000 lung patients will be newly diagnosed with a rearranged TK in the next future $[17,18]$.

We also speculate on the role of CCDC6 as common partner of at least two TK, ROS1 and RET, for its targeting in combined therapies including TKIs in lung cancer treatment. Given the prevalence of CCDC6 fusion to ROS1 and RET, this analysis will identify and tailor a treatment, with the aim to enhance the TKI efficacy and to prevent resistance in almost 1000 lung cancer patients.

\section{The lung paradigm of TK fusions and their targeting}

In lung, the somatic mutations of the EGFR gene are the best-characterized examples of oncogenic TK activation. Recently, however, TK fusions have been identified involving ALK, ROS1 and RET kinases in 3-7, 1-2, and $0.7-2 \%$ of lung cancer, respectively [16-18] (Fig. 1a).
The occurrence of the ALK, ROS1 and RET fusions seems to be mutually exclusive [19]. An early analysis of 1073 non-small cell lung cancer (NSCLC) specimens demonstrated no overlap between ROS1 and ALK rearrangements [20]. However, conflicting findings have subsequently been reported [21]. In the most recent and largest series to date, a total of 220 cases of ROS1rearranged NSCLCs were examined. Amongst these tumours, ROS1 rearrangements never overlap with ALK fusions, and rarely co-occurr with oncogenic EGFR mutations $(0.5 \% ; 1 / 220)$ or KRAS mutations $(1.8 \% ; 4 / 220)$ $[22,23]$. Thus, ROS1 rearrangements generally identify a unique molecular subset of NSCLC. Also the prevalence of the RET fusions greatly increases (from a median $1.8 \%$ to a significative $6.3 \%$ ) when evaluated in 159 lung cancer patients wild type for EGFR, ALK, ROS1, BRAF, KRAS, HER2 [24-26].

Anaplastic lymphoma kinase (ALK), firstly identified as fused to nucleophosmin in an anaplastic large-cell lymphoma cell line, is normally expressed in the brain, small intestine, and testis [27]. ALK, that shows sequence similarity to the insulin receptor subfamily of transmembrane tyrosine kinases, is still considered an orphan receptor, even though pleiotrophin (PTN) and midkine (MDK), both secreted growth factors, are known to activate ALK downstream signalling [28, 29]. However, PTN and MDK effects on ALK activity are not due to direct binding [30]. Recently, it has been shown that heparin chains induce ALK dimerization, activation, and downstream signalling, indicating that heparin serves as ALK ligand or coligand [31]. While ALK gene amplification has been detected in a variety of tumours and gain-of-function mutations of ALK are described primarily in neuroblastoma, the most prevalent genomic ALK aberrations in human cancer are chromosomal rearrangements. ALK rearrangements have been found in multiple malignancies, including lung cancer, neuroblastoma, rhabdomyosarcoma, renal cell carcinoma, and inflammatory breast cancer [32].

ROS1 encodes a receptor tyrosine kinase (RTK) evolutionarily conserved in C. elegans, D. melanogaster, and vertebrates. However, the biological role of native ROS1 in humans has not yet been defined, and it remains an orphan RTK without a known ligand [17, 33]. ROS1 rearrangement has been firstly reported in an adult glioblastoma tumour [34]. Since the initial description, ROS1 fusions have been later detected in a wide range of malignancies including inflammatory myofibroblastic tumour [35, 36], cholangiocarcinoma [37], ovarian cancer [38], gastric cancer [39], colorectal cancer [40], angiosarcoma [41], spitzoid melanoma [42], and NSCLC $[24,43-56]$.

RET encodes a RTK whose primary ligands belong to the glial-derived neurotrophic factor (GDNF) family 


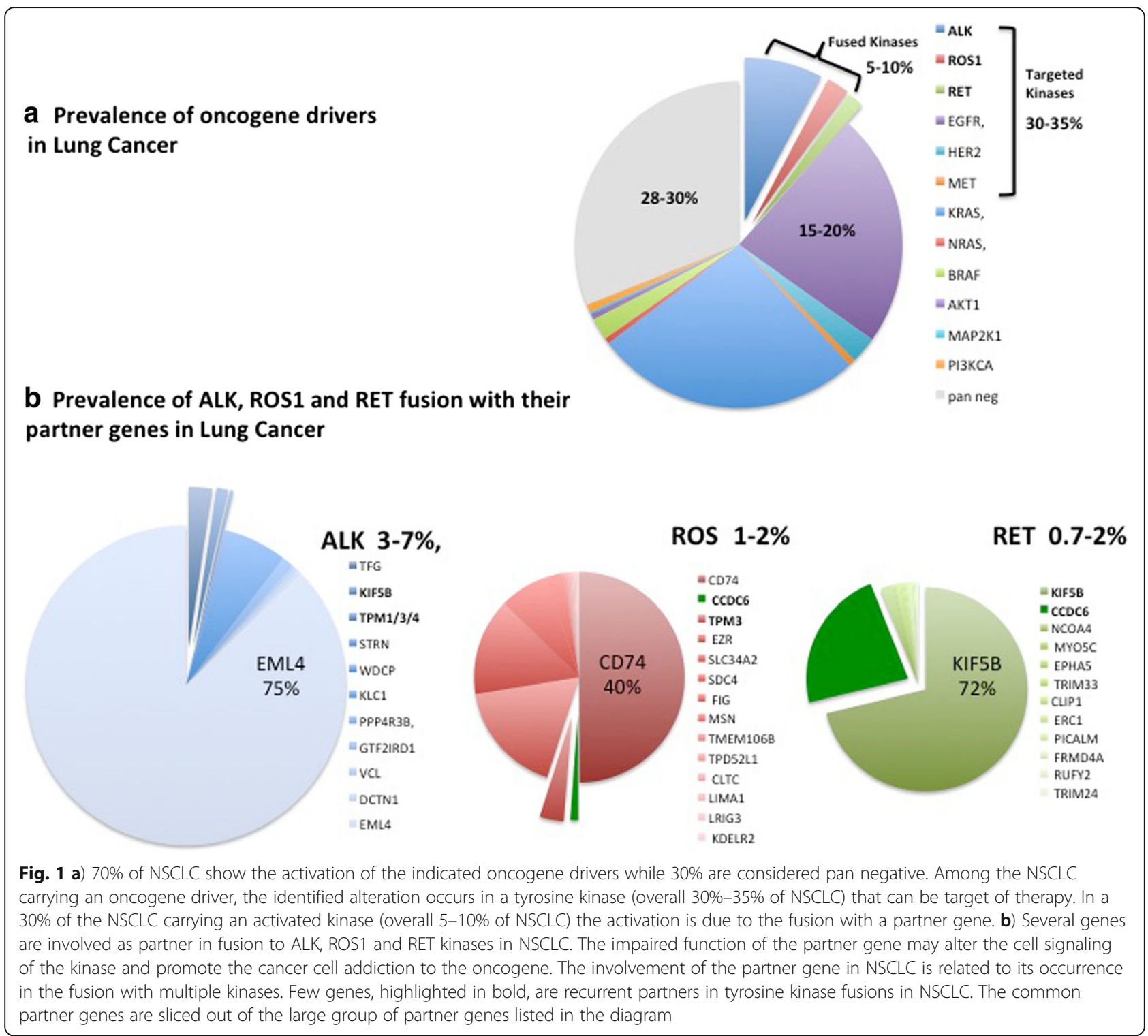

including GDNF, artemin, neurturin and persephin [57]. RET, specifically expressed on cells deriving from the neural crest, plays a key role mostly in organogenesis and development of the enteric nervous system [58, 59]. RET chromosomal rearrangements were initially identified in $5-40 \%$ of papillary thyroid cancers [18]. Furthermore, RET gain-of-function point mutations were also observed in up to $50 \%$ of sporadic medullary thyroid cancers [60] and the occurrence of germline mutations predispose patients to multiple endocrine neoplasia type 2 characterized by medullary thyroid cancer, pheochromocytoma and hyperparathyroidism [61]. Interestingly, RET somatic mutations were also described in small cell lung cancer patients [62-65] and cell lines [62, 66].

While ALK and ROS1 share a strong homology in the amino acidic sequence, with a $49 \%$ identity in the kinase domain and $77 \%$ identity in the ATP-binding site [44], ALK and RET share an homology of $37 \%$ in the amino acidic sequence of the kinase domain [67]. The identified homology provided the structural basis for a common targeting, at least for ALK and ROS1 [44]. Indeed, targeted therapies directed at constitutively activated oncogenic tyrosine kinases have proven to be remarkably effective against cancers carrying ALK and ROS1 fusions. In $3-7 \%$ of NSCLC patients who harbour the ALK fusions, the efficacy of the ALK directed TKI crizotinib have been reported in approximately 60\% [68-70]. Crizotinib demonstrated remarkable efficacy, reminiscent of responses in ALK-rearranged patients, also in ROS1-rearranged NSCLCs, consequently gaining quick approval by the United States Food and Drug Administration as well as the European Medicines Agency in 
2016. In fact, among 50 patients with ROS1-rearranged included in the phase I PROFILE 1001 study, crizotinib treatment resulted in an objective response rate (ORR) of $72 \%$, with disease control rate (DCR) of $90 \%$ and a median progression-free survival (PFS) of 19.2 months [44]. On the other hand, disappointingly, early results obtained in patients carrying the RET rearrangements indicate a modest level of efficacy compared with the results obtained so far with inhibitors of ALK and/or ROS1. In the clinical setting, the RET patient benefit in terms of response (16\% to $47 \%$ ), and PFS (2 to 7 months), is clearly not comparable to that seen with other targeted agents in NSCLC patient bearing EGFR mutation (ORR: 56\%-85\%, median PFS: 9.2-13.7 months) [71], ALK (ORR: 60\%-95\%, median PFS: 8-11 months) [72] or ROS1 (ORR: 65\%-85\%, median PFS: 9.1-19.3 months) rearrangements [73].

All the kinases ALK, ROS1 and RET enhance cell proliferation and survival via activation of common downstream pathways RAS/MAPK, PI3K/AKT and JAK/ STAT. However, extra-signalling pathways can be activated upon the TK fusions. The partner gene, besides affecting the stability of the fusion kinase, may drive the kinase activity on different substrates leading to the activation of additional signalling and to the alteration of the cellular metabolism [74-77]. Consequently, the switch-on/-off of numerous drivers and non-drivers genes confers cancer cells with "de novo" or acquired drug resistance. To this regard the partner gene fused to the tyrosine kinase may have specific role in the kinase activity as well as in the sensitivity of TK for its targeting. Several partner genes are fused to the mentioned kinases in lung. The most frequent derived-"driver oncogenes" are the echinoderm microtubule-associated protein-like 4 (EML4) fused to ALK, the kinesin family 5B (KIF-5B) fused to RET, and the cluster of differentiation 74 (CD74) fused to c-ros oncogene 1 (ROS1) which are closely involved in the therapeutic efficacy of each cognate targeting TKI [44, 78, 79] (Fig. 1a-b).

The EML4-ALK fusion occurs in 2-7\% of NSCLC patients and is particularly prevalent in younger individuals, relative to those with wild-type NSCLC, and in never and/or light smokers (<10 pack years) [24, 80, 81]. Following the discovery of this fusion in 2007, numerous additional ALK fusion partners have been identified, including TFG, KIF5B, KLC1, STRN, WDCP, TPM1/3/4, PPP4R3B, GTF2IRD1, VCL, and DCTN1 [1, 9] (Fig. 1b).

In the context of NSCLC, fusions involving ROS1 are described in 1-2\% of patients [82]. A total of 14 different ROS1 fusion partner genes have been reported until now in lung cancer, including CD74 [1, 4, 24, 45-47], SLC34A2 [43-47], SDC4 [24, 44], EZR [24, 44, 48, 49], FIG. (46, 50), TPM3 [24, 44], LRIG3 [24], KDELR2 [46], CCDC6 [52], MSN [44, 53], TMEM106B [54], TPD52L1
[55], CLTC [56], and LIMA1 [4] (Fig. 1b). All ROS1 fusions retain the entire ROS1 kinase domain [24]. Similar to the ALK fusions, NSCLC patients with ROS1 fusions are typically younger than those with ROS1-wild-type and are never or light smokers [45].

Genomic screens have also identified at least 12 genes which are partner in fusion with RET in NSCLC: KIF5B [24-26, 79], CCDC6 [24], NCOA4 [83], MYO5C [84], EPHA5 [83], TRIM33 [85], CLIP1 [85], ERC1 [86], PICALM [83], FRMD4A [86], RUFY2 [87], and TRIM24 [87] (Fig. 1b).

The partner genes involved in the TK fusions in lung typically encode proteins that contain dimerizationcompetent motifs, suggesting that TK activation is mediated by dimerization and/or oligomerization. However, unlike the ALK and RET fusion, ROS1 fusions can signal as monomers, the mechanism underlying the constitutive activity of this kinase being still unknown [24]. In the case of tumours bearing tyrosine kinase rearrangement and treated with tyrosine kinase inhibitors, the fusion partner should be considered a potential target of combinatorial therapy to more potently block the aberrant activity of the fusion protein and eventually to overcome resistance.

In the case of RET fusions, the TK signals through, at least, some canonical RET signalling pathways [88], although the full downstream effects of RET fusions have not been fully explored [89]. In vitro evidences show that mitogen-activated protein kinase (MAPK) inhibitors have a stronger effect against medullary thyroid carcinoma (MTC) human cancer cell lines, carrying point mutated isoforms of the RET kinase, than against a papillary thyroid carcinoma (PTC) human cancer cell line, carrying the CCDC6-RET fusion [90].

Moreover, when assayed in flies, the fusions CCDC6RET and NCOA4-RET exhibit differential sensitivity to clinically relevant kinase inhibitors, indicating that the signalling of RET fusion isoforms are at least in part dependent on the partner gene [14].

Accordingly, recent clinical studies suggest that different RET fusion variants might be differently sensitive to a specific TKI. In selected NSCLC, vandetanib (300 mg/day) was tested in a Japanese phase II study (LURET) including 17 RET-rearranged NSCLC patients, $31 \%$ of whom were CCDC6-RET-positive, 53\% were KIF5B-RET-rearranged, $16 \%$ had an unknown RET status [91]. Treatment response and survival outcome were much higher in patients with the CCDC6-RET fusion subtype, with an $83 \%$ ORR and median PFS of 8.3 months, compared to $20 \%$ and 2.9 months, respectively, for patients with the KIF5B-RET fusion variant [91]. It is reasonable that, like in the case of the RET fusion isoforms, also the other TK fusions reported in lung (ALK and ROS1), acting through distinct pathways, 
might show different sensibility to selected tyrosine kinase inhibitors. To date, however, no definitive conclusions about a potentially diverse efficacy of anti-TK therapies according to different TK fusion variants have been achieved, mostly because the relative low frequency of TK rearrangements has allowed the analysis of only small subgroups, generating discordant data. Thus, the identification of the most efficient drug for each TK fusion isoform still remains a significant unmet need [92-94].

To this end, it is also urgent to deeper understand the mechanisms of drug resistance. Although the specific pathways and molecules involved will vary, the general principles of how biological mechanisms of resistance should be addressed are likely to be similar across cancer types.

The bedside-to-bench studies have advanced the understanding of the different biological mechanisms causing different types of resistance. For "on-target" resistance, for example, the strategy that seems mostly effective is to obtain new and more potent inhibitor compounds. Indeed, new agents in clinical development have demonstrated promising activity in crizotinib and TKIs type I resistant patients [95]. Now it is needed to investigate in detail the mechanisms of resistance related to the specific molecular alterations carried by the tumour and, thus, in our case, the drivers of and/or the mechanisms underlying the "de novo" and acquired resistance for ALK, ROS and RET fusion kinases [96]. These studies are, indeed, expected to identify the rationale for targeting parallel/compensatory signalling that could be preferentially activated in TK fusion with selected partners. A combined therapy seems to represent a valid alternative option for tumours with "de novo" or acquired resistance to TK activation. Thus, for selected isoforms of TK fusions it would be necessary to define the therapeutic synergism between different TK inhibitors, also in combination with new drugs intended to target the fusion partner.

\section{CCDC6/TK fusions and challenge of combined therapy to overcome resistance}

Several genes have been identified as partners of TK fusions. Many of them are recurrent in fusions with different type of kinases, in different tumour types (Fig. 1b). The involvement of the same partner genes in different type of fusions might indicate that, besides the induction of the kinase activation, the partner gene might be functional to the full transformation and oncogene addiction of the cancer cells. The functional characterization of a partner gene frequently involved in TK fusions might help to select novel strategies for combined therapy in order to enhance the effects and/or overcome the resistance to the current treatments with TKIs.

In lung, four genes have been identified as recurrent partners in fusion with at least two of the three kinases rearranged. TPM-family genes and TFG (TRK-fused gene) have been found fused to ALK and ROS1 kinases in overall $5 \%$ of cases among those carrying a TK fusions; KIF5B is rearranged with both ALK and RET kinases in almost $70 \%$ of cases carrying a TK fusions, and CCDC6 is a common partner of ROS1 and RET kinases in about $25 \%$ of cases $[9,15,19]$ (Fig. 1b).

CCDC6 (coiled coil domain containing 6) is a ubiquitously expressed $65 \mathrm{kDa}$ nuclear and cytosolic protein phosphorylated by $\mathrm{S} / \mathrm{T}$ kinases, that exerts a negative regulation of the CREB1 transcriptional activity, in a SUMO2-regulated manner [97-101]. CCDC6 is involved in apoptosis, while its truncated mutant of 1-101aa, which corresponds to the portion of CCDC6 included in the CCDC6-RET fusion, acts as dominant negative on CCDC6 nuclear localization and apoptotic function [97]. CCDC6 is an ATM substrate at T434 and is involved in ATM-mediated cellular-response [98]. Following genotoxic stress, CCDC6 interacts with PP4c and negatively modulates the phosphatase enzymatic activity toward the dephosphorylation on $\mathrm{S} 139$ of the histone H2AX $(\gamma \mathrm{H} 2 \mathrm{AX})$, the specific marker and efficient coordinator of the DNA repairing process. Thus, in CCDC6 depleted cells, the loss or inactivation of CCDC6 accelerates the dephosphorylation of $\gamma \mathrm{H} 2 \mathrm{AX}$, resulting in defective checkpoint activation, defective G2 arrest and premature mitotic entry. Moreover, CCDC6 depleted cells affects the $\gamma \mathrm{H} 2 \mathrm{AX}$ foci formation and favors the repair of the DNA DSBs repair by non-homologous-end-joining more prone to errors than homologous recombination, in a shorter time compared to controls [99]. Of notice, the tumor suppressor DNA repair function of CCDC6 has been found lost, by several mechanisms, in many human cancer [102].

CCDC6 has been involved in different rearrangements with several tyrosine kinases (RET, PDGFRb, ROS1, FGFR2) in several tumours (thyroid, lung, leukemia, breast, iCCA) [102] (Fig. 2).

In CCDC6-TK fusions, CCDC6 contributes with portions of different length of its protein [102] (Fig. 2). When rearranged with RET, CCDC6 contributes aminoterminus portions corresponding to 101aa, identified in most of the cases of lung and thyroid tumours, or portions corresponding to $150 \mathrm{aa}$ or $293 \mathrm{aa}$, reported at very low percentage in thyroid tumours [24, 103-105]. In leukemia, CCDC6 rearranged with PDGFR $\beta$ contributes an aminoterminus portion of 368 aminoacids [106]. In breast and iCCA, a FGFR2-CCDC6 fusion has been recently identified and the CCDC6 gene contributes the coiled coil region at the $3^{\prime}$ terminus of the chimeric oncogenes [6, 107] (Fig. 2).

It will be important to evaluate whether the different lenghts of the CCDC6 portion included in the fusions could influence the stability of the oncogenic kinase and 


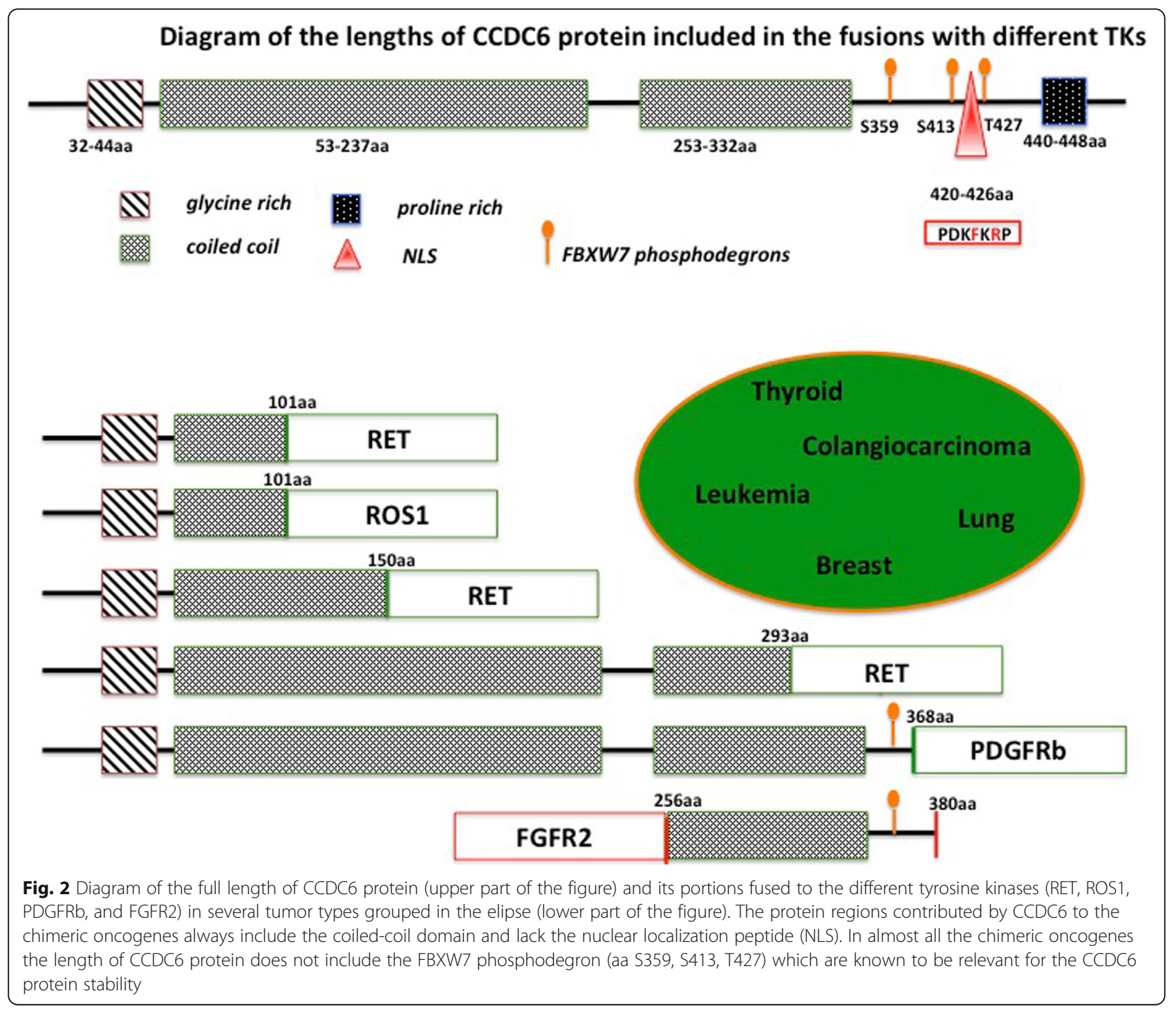

its sensitivity to different drugs. Accordingly, strong evidences suggest that the ALK tyrosine kinase activity is not the only driving force for oncogenesis in EML4-ALK positive NSCLC. In case of EML4-ALK fusions, there are many evidences suggesting that the specific targeting of EML4 can be a rewarding strategy to avoid resistance. Fifteen different EML4-ALK variants contain the entire ALK kinase domain but differ in the point of fusion with the EML4 gene including the EML4 TD domain required for oligomerization of the fusion proteins but diverging in the length of the EML4 TAPE domain present [108-111]. In vitro studies have demonstrated that the length of the TAPE domain greatly influences fusion protein stability: the EML4-ALK variants 1 and 2, expressing a partial TAPE domain, are more unstable than variant $3 \mathrm{a} / \mathrm{b}$ that lacks the TAPE domain. Remarkably, this has enormous clinical impact, as the more stable variants are less sensitive to ALK inhibitors as demonstrated in preclinical studies and by retrospective studies of NSCLC patients expressing different fusion variants and treated with crizotinib [112, 113]. Thus, the different length of the EML-4 TAPE domain in EML4ALK variants, determining the stability of the fusion proteins, has relevant biochemical consequences and clinical implications [112, 113].

Several evidence suggest that most of the oncogenic kinases rely on chaperone proteins, such as HSP90, for stability. The 17-DMAG HSP90 inhibitor has been tested in $\mathrm{Ba} / \mathrm{F} 3$ cells expressing different EML4-ALK variants. Remarkably, sensitivity to ALK kinase inhibition did not correlate with sensitivity to 17-DMAG. Moreover, the combination of crizotinib and 17-DMAG induced synergistic cytotoxicity in all ALK fusion-expressing cells, with the maximal synergistic cytotoxicity observed in cells expressing the most stable EML4-ALK variant 3a [112]. 
CCDC6 stability and turnover are highly regulated by post-translational modifications following the phosphodegron recognition (Fig. 2) by the E3-Ubiquitin ligase, FBXW7, and upon the activity of the de-ubiquitinase enzyme, USP7 [114]. The targeting of USP7 to reduce CCDC6 levels appears to be useful for the establishment of new therapeutic approaches in cancer treatment [115-117], since it could also affect the stability and turnover of the TKs fused to CCDC6. Combined effects of the inhibitors of USP7 and TKI should be investigated in lung tumours carrying the CCDC6/TK fusions.

In addition to the hypothetical role of CCDC6 on the TK stability and on the development of "on-target" resistance, the impairment of CCDC6 in tumours carrying the fusions may induce "off targets" effects as well as "off targets" resistance. It has been recently postulated that the CCDC6 impairment derived from its truncation in fusion oncogenes, enhances tumour progression and impacts on selective response to therapeutics offering new chances for a tailored therapy and novel challenges to overcome drug resistance [118].

CCDC6 has been identified as a negative regulator of CREB1 dependent transcription and tumours harboring the CCDC6-RET oncogene or occurring in Ccdc6-ex2 knock-in mice exhibit an enhanced phosphorylation and activity of CREB1 with a consequent increased expression of Amphiregulin (AREG) one of the known ligand for the EGFR family $[100,119,120]$. The autocrine production of Amphiregulin (AREG) is a parallel compensatory survival signaling responsible of "off-targets" TKIs resistance identified in different tumour types. Moreover, recent findings have shown that EGFR signaling can provide a critical adaptive survival mechanism that allows cancer cells to evade kinase fusion specific inhibitors, providing a rationale to co-target EGFR in order to reduce risks of developing drug resistance [121]. If this molecular mechanism will prove to be crucial for cancer cell proliferation, the absence of CCDC6 may have important therapeutic effects for the targeting of the EGFR family members in determined tumours [122], (Fig. 3).

Interestingly, the activation of epidermal growth factor (EGF) is known to trigger resistance to RET inhibitors, bypassing survival signaling through ERK and AKT activation. Targeting EGFR using specific TKIs like gefitinib brings back cancer cells sensitivity to RET inhibitors [120]. Furthermore, the inhibition of the EGF signaling by EGFR small interfering RNA (siRNA), anti-EGFR antibody (cetuximab), and EGFR-TKi (Iressa) determined an increase in the sensitivity to RET inhibitors in lung cancer cells carrying CCDC6-RET fusion [123] (Fig. 3). Thus, if a role can be ascribed to CCDC6 in the activation of the EGFR signaling, the detection of CCDC6 impairment upon TK fusion could represent an indication for targeting EGFR in cancer therapy (Cerrato A, Di Domenico I,
Morra F, Celetti A, manuscript in preparation). Therefore a sequential or combined treatment scheme by small molecules inhibitors can be envisaged (Fig. 3).

In both preclinical and clinical studies, evidences suggest that CCDC6-RET fusion is selectively responsive to vandetanib compared to NCOA4-RET and KIF5BRET fusions. This finding may support the fact that RET fusions involving CCDC6 are more sensitive to TK inhibitors that can inhibit also the EGFR signaling as "off target" effect [14, 102].

Interestingly, the activation of CCDC6-RET has been identified in post progression samples of lung cancer patients, which developed resistance to EGFR TKIs [124]. Thus, the inactivation of CCDC6 in combination with the activation of RET could be identified as additional mechanism of EGFR TKIs resistance, beside the EGFR T790 M mutation, EGFR amplification, HER2 amplification, MET amplification, PIK3CA mutation, BRAF mutation $[125,126]$.

On these bases, TKIs that show "off targets" effects like vandetanib might be more effective in those cases in which RET TK activation is combined with the enhancement of EGFR signaling because of the CCDC6 impairment. In particular, "off targets" effects of TKIs could be considered a better therapeutic option in thyroid or lung tumours that carry CCDC6/RET fusion protein, in order to avoid tumour progression and TKIs resistance (Fig. 3). Moreover, loss or inactivation of CCDC6 in cancers, by accelerating the dephosphorylation of the histone $\gamma \mathrm{H} 2 \mathrm{AX}$ results in defective $\mathrm{G} 2$ arrest and premature mitotic entry [99]. This suggests that tumours with defective CCDC6 signaling could be sensitive to the combination of DNAdamaging and anti-mitotic drugs [127-129].

Preclinical studies indicate that the attenuation of CCDC6 in cancer confers resistance to cisplatinum and sensitizes the cancer cells to the small molecule inhibitors of Poly (ADP-ribose) polymerase (PARP1/2) in accordance with its role in the DNA damage response [91, 130-132]. The important role of CCDC6 in the DNA damage could impact genome stability in primary tumours [133], as reported also for other genes whose products participate in DDR and are commonly deregulated or inactivated in tumors [134]. CCDC6 impairment upon fusions, altering the DDR process in TK addicted cells, might promote the tumour heterogeneity by enhancing ongoing error-prone DNA replication with differential selection pressures and drug sensitivity [135] (Fig. 3). Thus, CCDC6, when fused to ROS1 and RET kinase, could be imagined as a predictive biomarker of resistance to conventional single mode therapy and provides indications about the tumour sensitivity to PARPi in combination with TKI in NSCLC. A combination therapy of TKIs and PARPi should be valuable in lung or different cancer types that result defective for CCDC6 


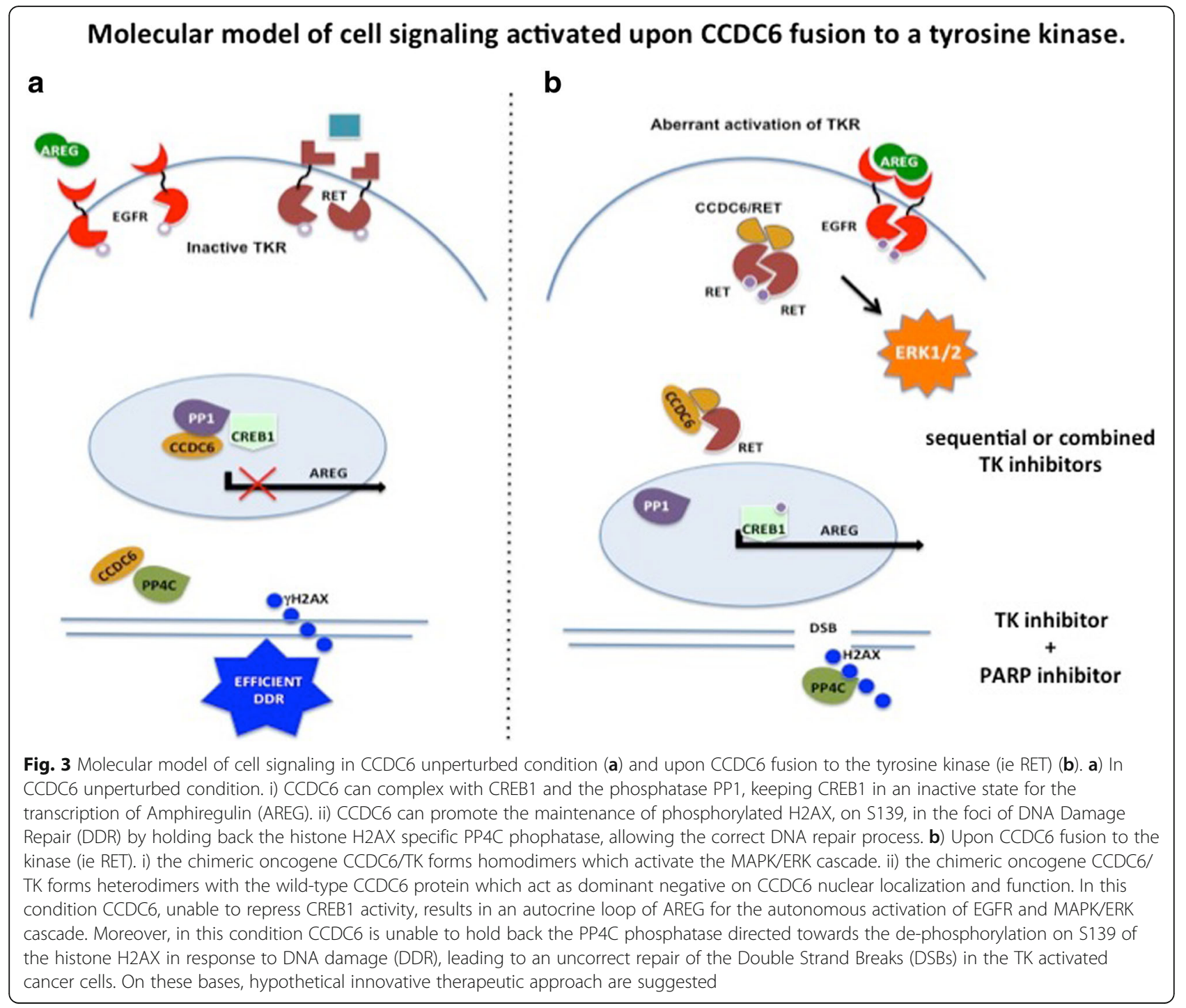

because of qualitative targeting of tumour over nontumour cells (Fig. 3).

\section{Conclusion}

In conclusions, it is plausible to envision a future in which the different TK fusion variants of CCDC6-ROS1 and CCDC6-RET will be used as biomarkers of sensitivity to therapy with TK inhibitors in combination with drugs targeting protein stability, such as chaperone, proteasome, and deubiquitinase inhibitors.

Moreover, in cancers carrying kinase fusion and actionable partners, an improved final outcome of the disease should be attained when a strategy of combined therapy is utilized, with a reduction of the side effects due to the conventional therapy. For example, the combined treatment with diverse TKIs, including gefitinib, should target preferentially the tumour cells carrying CCDC6 rearrangements, while normal cells should be more resistant to the combination of these two drugs.

Tumours carrying the CCDC6 fusion might be prone to the tumour heterogeneity because of errorprone DNA replication leading to a different selection pressure upon TK targeting. Thus, patients carrying CCDC6/TK fusion may benefit of a combined therapy of TKI and PARPi in order to avoid selection of TKI resistant cancer cells.

Authors' contributions

All authors read and approved the final manuscript.

Competing interests

The authors declare that they have no competing interest.

\section{Publisher's Note}

Springer Nature remains neutral with regard to jurisdictional claims in published maps and institutional affiliations. 


\section{Received: 8 January 2018 Accepted: 1 February 2018}

\section{Published online: 19 February 2018}

\section{References}

1. Stransky N, Cerami E, Schalm S, Kim JL, Lengauer C. The landscape of kinase fusions in cancer. Nat Commun. 2014;5:4846.

2. Mitelman F, Johansson B, Mertens F. The impact of translocations and gene fusions on cancer causation. Nat Rev Cancer. 2007;7:233-45.

3. Chmielecki J, Peifer M, Jia P, Socci ND, Hutchinson K, Viale A, et al. Targeted next-generation sequencing of DNA regions proximal to a conserved GXGXXG signaling motif enables systematic discovery of tyrosine kinase fusions in cancer. Nucleic Acids Res. 2010;38:6985-96.

4. Wang R, Hu H, Pan Y, Li Y, Ye T, Li C, et al. RET fusions define a unique molecular and clinicopathologic subtype of non-small-cell lung cancer. J Clin Oncol. 2012;30:4352-9.

5. Hutchinson KE, Lipson D, Stephens PJ, Otto G, Lehmann BD, Lyle PL, et al. BRAF fusions define a distinct molecular subset of melanomas with potential sensitivity to MEK inhibition. Clin Cancer Res. 2013;19:6696-02.

6. Wu Y-M, Su F, Kalyana-Sundaram S, Khazanov N, Ateeq B, Cao X, et al. Identification of targetable FGFR gene fusions in diverse cancers. Cancer Discov. 2013;3:636-47.

7. Parker BC, Zhang W. Fusion genes in solid tumors: an emerging target for cancer diagnosis and treatment. Chin J Cancer. 2013;32:594-603.

8. Majewski IJ, Mittempergher L, Davidson NM, Bosma A, Willems SM, Horlings $\mathrm{HM}$, et al. Identification of recurrent FGFR3 fusion genes in lung cancer through kinome-centred RNA sequencing. J Pathol. 2013;230:270-6.

9. Shaw AT, Hsu PP, Awad MM, Engelman JA. Tyrosine kinase gene rearrangements in epithelial malignancies. Nat Rev Cancer. 2013;13:772-87.

10. Ciampi R, Knauf JA, Kerler R, Gandhi M, Zhu Z, Nikiforova MN, et al. Oncogenic AKAP9-BRAF fusion is a novel mechanism of MAPK pathway activation in thyroid cancer. J Clin Invest. 2005;115:94-101.

11. Vogelstein B, Papadopoulos N, Velculescu VE, Zhou S, Diaz LA Jr, Kinzler KW. Cancer genome landscapes. Science. 2013;339:1546-58.

12. Kumar-Sinha C, Kalyana-Sundaram S, Chinnaiyan AM. Landscape of gene fusions in epithelial cancers: seq and ye shall find. Genome Med. 2015;7:129.

13. Singh J, Petter RC, Baillie TA, Whitty A. The resurgence of covalent drugs. Nat Rev Drug Discov. 2011;10:307-17.

14. Levinson S, Cagan RL. Drosophila Cancer models identify functional differences between ret fusions. Cell Rep. 2016;16:3052-61.

15. Schram AM, Chang MT, Jonsson P, Drilon A. Fusions in solid tumours: diagnostic strategies, targeted therapy, and acquired resistance. Nat Rev Clin Oncol. 2017;14:735-48.

16. Qin A, Gadgeel S. The current landscape of anaplastic lymphoma kinase (ALK) in non-small cell lung cancer: emerging treatment paradigms and future directions. Target Oncol. 2017;12:709-18.

17. Lin JJ, Shaw AT. Recent advances in targeting ROS1 in lung cancer. J Thorac Oncol. 2017;12:1611-25.

18. Ferrara R, Auger N, Auclin E, Besse B. Clinical and translational implications of RET rearrangements in non-small cell lung cancer. J Thorac Oncol. 2018;13(1):27-45.

19. Camidge DR, Pao W, Sequist LV. Acquired resistance to TKls in solid tumours: learning from lung cancer. Nat Rev Clin Oncol. 2014;11:473-81.

20. Bergethon K, Shaw AT, Ou SH, Katayama R, Lovly CM, McDonald NT, et al. ROS1 rearrangements define a unique molecular class of lung cancers. J Clin Oncol. 2012;30:863-70.

21. Gainor JF, Varghese AM, Ou SH, Kabraji S, Awad MM, Katayama R, et al. ALK rearrangements are mutually exclusive with mutations in EGFR or KRAS: an analysis of 1,683 patients with non-small cell lung cancer. Clin Cancer Res. 2013;19:4273-81.

22. Wiesweg M, Eberhardt WE, Reis H, Ting S, Saviddou N, Skiba C, et al. High prevalence of concomitant oncogene mutations in prospectively identified patients with ROS1-positive metastatic lung cancer. J Thorac Oncol. 2017:12:54-64

23. Lin JJ, Ritterhouse LL, Ali SM, Bailey M, Schrock AB, Jainor JF, et al. ROS1 fusions rarely overlap with other oncogenic drivers in non-small cell lung cancer. J Thorac Oncol. 2017:12:872-7.

24. Takeuchi K, Soda M, Togashi Y, Suzuki R, Sakata S, Hatano S, et al. RET, ROS1 and ALK fusions in lung cancer. Nat Med. 2012;18:378-81.

25. Lipson D, Capelletti M, Yelensky R, Otto G, Parker A, Jarosz M, et al. Identification of new ALK and RET gene fusions from colorectal and lung cancer biopsies. Nat Med. 2012;18:382-4.
26. Ju YS, Lee WC, Shin JY, Lee S, Bleazard T, Won JK, et al. A transforming KIF5B and RET gene fusion in lung adenocarcinoma revealed from whole-genome and transcriptome sequencing. Genome Res. 2012;22:436-45.

27. Morris SW, Kirstein MN, Valentine MB, Dittmer KG, Shapiro DN, Saltman DL, et al. Fusion of a kinase gene, ALK, to a nucleolar protein gene, NPM, in non-Hodgkin's lymphoma. Science. 1994;263:1281-4.

28. Stoica GE, Kuo A, Aigner A, Sunitha I, Souttou B, Malerczyk C, et al. Identification of anaplastic lymphoma kinase as a receptor for the growth factor pleiotrophin. J Biol Chem. 2001;276:16772-9.

29. Stoica GE, Kuo A, Powers C, Bowden ET, Sale EB, Riegel AT, et al. Midkine binds to anaplastic lymphoma kinase (ALK) and acts as a growth factor for different cell types. J Biol Chem. 2002;277:35990-8.

30. Moog-Lutz C, Degoutin J, Gouzi JY, Frobert Y, Brunet-de Carvalho N, Bureau $J$, et al. Activation and inhibition of anaplastic lymphoma kinase receptor tyrosine kinase by monoclonal antibodies and absence of agonist activity of pleiotrophin. J Biol Chem. 2005:280:26039-48.

31. Murray PB, Lax I, Reshetnyak A, Ligon GF, Lillquist JS, Natoli EJ Jr, et al. Heparin is an activating ligand of the orphan receptor tyrosine kinase ALK. Sci Signal. 2015;8:ra6.

32. Holla VR, Elamin YY, Bailey AM, Johnson AM, Litzenburger BC, Khotskaya YB, et al. ALK: a tyrosine kinase target for cancer therapy. Cold Spring Harb Mol Case Stud. 2017:3:a001115.

33. Acquaviva J, Wong R, Charest A. The multifaceted roles of the receptor tyrosine kinase ROS in development and cancer. Biochim Biophys Acta. 2009;1795(1):37-52. https://doi.org/10.1016/j.bbcan.

34. Birchmeier C, Sharma S, Wigler M. Expression and rearrangement of the ROS1 gene in human glioblastoma cells. Proc Natl Acad Sci U S A. 1987;84:9270-4

35. Lovly CM, Gupta A, Lipson D, Otto G, Brennan T, Chung CT, et al. Inflammatory myofibroblastic tumors harbor multiple potentially actionable kinase fusions. Cancer Discov. 2014:4:889-95.

36. Yamamoto H, Yoshida A, Taguchi K, Kohashi K, Hatanaka Y, Yamashita A, et al. ALK, ROS1 and NTRK3 gene rearrangements in inflammatory myofibroblastic tumours. Histopathology. 2016;69:72-83.

37. Gu TL, Deng X, Huang F, Kohashi K, Hatanaka Y, Yamashita A, et al. Survey of tyrosine kinase signaling reveals ROS kinase fusions in human cholangiocarcinoma. PLoS One. 2011:6:e15640.

38. Birch AH, Arcand SL, Oros KK, Rahimi K, Watters AK, Provencher D, et al. Chromosome 3 anomalies investigated by genome wide SNP analysis of benign, low malignant potential and low grade ovarian serous tumours. PLoS One. 2011:6:e28250.

39. Lee J, Lee SE, Kang SY, Do IG, Lee S, Ha SY, et al. Cancer. 2013;119:1627-35.

40. Aisner DL, Nguyen TT, Paskulin DD, Le AT, Haney J, Schulte N, et al. ROS1 and ALK fusions in colorectal cancer, with evidence of intratumoral heterogeneity for molecular drivers. Mol Cancer Res. 2014;12:111-8.

41. Giacomini CP, Sun S, Varma S, Shain AH, Giacomini MM, Balagtas J, et al. Breakpoint analysis of transcriptional and genomic profiles uncovers novel gene fusions spanning multiple human cancer types. PLoS Genet. 2013;9:e1003464.

42. Wiesner T, He J, Yelensky R, Esteve-Puig R, Botton T, Yeh I, et al. Kinase fusions are frequent in Spitz tumours and spitzoid melanomas. Nat Commun. 2014:5:3116.

43. Rikova K, Guo A, Zeng Q, Possemato A, Yu J, Haack H, et al. Global survey of phosphotyrosine signaling identifies oncogenic kinases in lung cancer. Cell. 2007;131:1190-203.

44. Shaw AT, Ou SH, Bang YJ, Camidge DR, Solomon BJ, Salgia R, et al. Crizotinib in ROS1-rearranged non-small-cell lung cancer. N Engl J Med. 2014;371:1963-71.

45. Davies KD, Le AT, Theodoro MF, Skokan MC, Aisner DL, Berge EM, et al. Identifying and targeting ROS1 gene fusions in non- small cell lung cancer. Clin Cancer Res. 2012:18:4570-9.

46. Rimkunas VM, Crosby KE, Li D, Hu Y, Kelly ME, Gu TL, et al. Analysis of receptor tyrosine kinase ROS1-positive tumors in non-small cell lung cancer: identification of a FIG-ROS1 fusion. Clin Cancer Res. 2012:18:4449-57.

47. Li C, Fang R, Sun Y, Han X, Li F, Gao B, et al. Spectrum of oncogenic driver mutations in lung adenocarcinomas from east Asian never smokers. PLoS One. 2011;6:e28204

48. Arai $Y$, Totoki $Y$, Takahashi $H$, Nakamura $H$, Hama $N$, Kohno $T$, et al. Mouse model for ROS1-rearranged lung cancer. PLoS One. 2013;8:e56010. 
49. Yoshida A, Kohno T, Tsuta K, Wakai S, Arai Y, Shimada Y, et al. ROS1rearranged lung cancer: a clinicopathologic and molecular study of 15 surgical cases. Am J Surg Pathol. 2013;37:554-62.

50. Suehara Y, Arcila M, Wang L, Hasanovic A, Ang D, Ito T, et al. Identification of KIF5B-RET and GOPC-ROS1 fusions in lung adenocarcinomas through a comprehensive mRNA-based screen for tyrosine kinase fusions. Clin Cancer Res. 2012;18:6599-608.

51. Govindan R, Ding L, Griffith M, Subramanian J, Dees ND, Kanchi KL, et al Genomic landscape of non-small cell lung cancer in smokers and neversmokers. Cell. 2012;150:1121-34.

52. Seo JS, Ju YS, Lee WC. The transcriptional landscape and mutational profile of lung adenocarcinoma. Genome Res. 2012;22:2109-19.

53. Zheng Z, Liebers M, Zhelyazkova B, Cao Y, Panditi D, Lynch KD, et al. Anchored multiplex PCR for targeted next- generation sequencing. Nat Med. 2014;20(12):1479-84. https://doi.org/10.1038/nm.3729.

54. Ou SH, Chalmers ZR, Azada MC, Ross JS, Stephens PJ, Ali SM, et al. Identification of a novel TMEM106B-ROS1 fusion variant in lung adenocarcinoma by comprehensive genomic profiling. Lung Cancer. 2015;88:352-4

55. Zhu WW, Upadhyay D, Schrock AB, Gowen K, Ali SM, Ou SH. TPD52L1-ROS1, a new ROS1 fusion variant in lung adenosquamous cell carcinoma identified by comprehensive genomic profiling. Lung Cancer. 2016;97:48-50.

56. Cancer Genome Atlas Research Network. Comprehensive molecular profiling of lung adenocarcinoma. Nature. 2014;511:543-50.

57. Airaksinen MS, Saarma M. The GDNF family: signalling, biological functions and therapeutic value. Nat Rev Neurosci. 2002;3:383-94.

58. Takahashi M, Buma $Y$, Iwamoto $\mathrm{T}$, Inaguma $\mathrm{Y}$, Ikeda $\mathrm{H}$, Cloning $\mathrm{HH}$. Expression of the ret proto-oncogene encoding a tyrosine kinase with two potential transmembrane domains. Oncogene. Oncogene. 1988;3(5):571-8.

59. Manié $S$, Santoro $M$, Fusco A, Billaud $M$. The RET receptor: function in development and dysfunction in congenital malformation. Trends Genet. 2001;17:580-9.

60. Marsh DJ, Learoyd DL, Andrew SD, Krishnan L, Pojer R, Richardson AL, et al. Somatic mutations in the RET proto-oncogene in sporadic medullary thyroid carcinoma. Clin Endocrinol. 1996;44:249-57.

61. Zbuk KM, Eng C. Cancer phenomics: RET and PTEN as illustrative models. Nat Rev Cancer. 2007;7:35-45.

62. Dabir S, Babakoohi S, Kluge A, Morrow JJ, Kresak A, Yang M, et al. J Thorac Oncol. 2014;9:1316-23.

63. Peifer M, Fernández-Cuesta L, Sos ML, George J, Seidel D, Kasper LH, et al. Integrative genome analyses identify key somatic driver mutations of smallcell lung cancer. Nat Genet. 2012;44:1104-10.

64. Rudin CM, Durinck S, Stawiski EW, Poirier JT, Modrusan Z, Shames DS, et al, Comprehensive genomic analysis identifies SOX2 as a frequently amplified gene in small-cell lung cancer. Nat Genet. 2012;44:1111-6.

65. Futami H, Egawa S, Tsukada T, Maruyama K, Bandoh S, Noguchi M, et al. A novel somatic point mutation of the RET proto-oncogene in tumor tissues of small cell lung cancer patients. Jpn J Cancer Res. 1995;86:1127-30.

66. Barretina J, Caponigro G, Stransky N, Venkatesan K, Margolin AA, Kim S, et al. The cancer cell line encyclopedia enables predictive modelling of anticancer drug sensitivity. Nature. 2012;483:603-7.

67. Ishizaka Y, Itoh F, Tahira T, Ikeda I, Sugimura T, Tucker J, et al. Human ret proto-oncogene mapped to chromosome 10q11.2. Oncogene. 1989;4(12):1519-21.

68. Shaw AT, Kim DW, Nakagawa K, Seto T, Crinó L, Ahn MJ, et al. Crizotinib versus chemotherapy in advanced ALK-positive lung cancer. N Engl J Med. 2013;368:2385-94.

69. Kwak EL, Bang YJ, Camidge DR, Shaw AT, Solomon B, Maki RG, et al. Anaplastic lymphoma kinase inhibition in non-small-cell lung cancer. N Engl J Med. 2010;363:1693-703.

70. Camidge DR, Bang YJ, Kwak EL, lafrate AJ, Varella-Garcia M, Fox SB, et al. Activity and safety of crizotinib in patients with ALK-positive non-small-cell lung cancer: updated results from a phase 1 study. Lancet Oncol. 2012;13:1011-9.

71. Castellano E, Feld E, Horn L. Driven by mutations: the predictive value of mutation subtype in EGFR-mutated non-small cell lung cancer. J Thorac Oncol. 2017;12:612-23

72. Caccese M, Ferrara R, Pilotto S, Carbognin L, Grizzi G, Caliò A, et al. Current and developing therapies for the treatment of non-small cell lung cancer with ALK abnormalities: update and perspectives for clinical practice. Expert Opin Pharmacother. 2016;17:2253-66.
73. Facchinetti F, Rossi G, Bria E, Soria JC, Besse B, Minari R, et al. Oncogene addiction in non-small cell lung cancer: focus on ROS1 inhibition. Cancer Treat Rev. 2017;55:83-95.

74. Portella G, Vitagliano D, Borselli C, Melillo RM, Salvatore D, Rothstein JL, et al. Human N-ras, TRK-T1, and RET/PTC3 oncogenes, driven by a thyroglobulin promoter, differently affect the expression of differentiation markers and the proliferation of thyroid epithelial cells. Oncol Res. 1999;11(9):421-7.

75. Borrello MG, Alberti L, Fischer A, Degl'innocenti D, Ferrario C, Gariboldi M, et al. Induction of a proinflammatory program in normal human thyrocytes by the RET/PTC1 oncogene. Proc Natl Acad Sci U S A. 2005;102:14825-30.

76. Puxeddu E, Knauf JA, Sartor MA, Mitsutake N, Smith EP, Medvedovic M, et al RET/PTC-induced gene expression in thyroid PCCL3 cells reveals early activation of genes involved in regulation of the immune response. Endocr Relat Cancer. 2005;12:319-34.

77. Musholt TJ, Brehm C, Hanack J, von Wasielewski R, Musholt PB. Identification of differentially expressed genes in papillary thyroid carcinomas with and without rearrangements of the tyrosine kinase receptors RET and/or NTRK1. J Surg Res. 2006;131:15-25.

78. Soda M, Choi YL, Enomoto M, Takada S, Yamashita Y, Ishikawa S, et al, Identification of the transforming EML4-ALK fusion gene in non-small-cell lung cancer. Nature. 2007:448:561-6.

79. Kohno T, Ichikawa H, Totoki Y, Yasuda K, Hiramoto M, Nammo T, et al. KIF5B-RET fusions in lung adenocarcinoma. Nat Med. 2012;18:375-7.

80. Wong DW, Leung EL, So KK, Tam IY, Sihoe AD, Cheng LC, et al. The EML4-ALK fusion gene is involved in various histologic types of lung cancers from nonsmokers with wild-type EGFR and KRAS. Cancer. 2009;115:1723-33.

81. Pan Y, Zhang Y, Li Y, Hu H, Wang L, Li H, et al. ALK, ROS1 and RET fusions in 1139 lung adenocarcinomas: a comprehensive study of common and fusion pattern-specific clinicopathologic, histologic and cytologic features. Lung Cancer. 2014;84:121-6.

82. Davies KD, Doebele RC. Molecular pathways: ROS1 fusion proteins in cancer. Clin Cancer Res. 2013;19:4040-5.

83. Gautschi O, Milia J, Filleron T, Wolf J, Carbone DP, Owen D, et al. Targeting RET in patients with RET-rearranged lung cancers: results from the global, multicenter RET registry. J Clin Oncol. 2017;35:1403-10.

84. Lee SH, Lee JK, Ahn MJ, Kim DW, Sun JM, Keam B, et al. Vandetanib in pretreated patients with advanced non-small cell lung cancerharboring RET rearrangement: a phase II clinical trial. Ann Oncol. 2017;28(2):292-7.

85. Drilon A, Rekhtman N, Arcila M, Wang L, Ni A, Albano M, et al. Cabozantinib in patients with advanced RET-rearranged non-small-cell lung cancer: an open-label, single-centre, phase 2, single-arm trial. Lancet Oncol. 2016:17:1653-60.

86. Velcheti V, Thawani R, Khunger M, Mukhopadhyay S, Chute DJ, Schrock AB, et al. FRMD4A/RET: a novel RET oncogenic fusion variant in non-small cell lung carcinoma. J Thorac Oncol. 2017;12:e15-6.

87. Farago AF, Le LP, Zheng Z, Muzikansky A, Drilon A, Patel M, et al. Durable clinical response to Entrectinib in NTRK1-rearranged non-small cell lung cancer. J Thorac Oncol. 2015;10:1670-4.

88. Castellone MD, Santoro M. Dysregulated RET signalling in thyroid cancer. Endocrinol Metab Clin N Am. 2008;37:363-74.

89. Knostman KA, Venkateswaran A, Zimmerman B, Capen CC, Jhiang SM. Creation and characterization of a doxycycline-inducible mouse model of thyroid-targeted RET/PTC1 oncogene and luciferase reporter gene coexpression. Thyroid. 2007;17:1181-8.

90. Gild ML, Landa I, Ryder M, Ghossein RA, Knauf JA, Fagin JA. Targeting mTOR in RET mutant medullary and differentiated thyroid cancer cells. Endocr Relat Cancer. 2013;20:659-67.

91. Yoh K, Seto T, Satouchi M, Nishio M, Yamamoto N, Murakami H, et al. Vandetanib in patients with previously treated RET-rearranged advanced non-small-cell lung cancer (LURET): an open-label, multicentre phase 2 trial. Lancet Respir Med. 2017;5:42-50.

92. Borrello MG, Ardini E, Locati LD, Greco A, Licitra L, Pierotti MA. RET inhibition: implications in cancer therapy. Expert Opin Ther Targets. 2013;17:403-19.

93. Horiike A, Takeuchi K, Uenami T, Kawano Y, Tanimoto A, Kaburaki K, et al. Sorafenib treatment for patients with RET fusion-positive non-small cell lung cancer. Lung Cancer. 2016;93:43-6.

94. Xing M, Haugen BR, Schlumberger M. Progress in molecular-based management of differentiated thyroid cancer. Lancet. 2013;381:1058-69. 
95. Karachaliou N, Sosa AE, Barron FB, Gonzalez Cao M, Santarpia M, Rosell R. Pharmacological management of relapsed/refractory NSCLC with chemical drugs. Expert Opin Pharmacother. 2017;8:295-304.

96. Drizou M, Kotteas EA, Syrigos N. Treating patients with ALK-rearranged nonsmall-cell lung cancer: mechanisms of resistance and strategies to overcome it. Clin Transl Oncol. 2017;19:658-66.

97. Celetti A, Cerrato A, Merolla F, Vitagliano D, Vecchio G, Grieco M. H4(D10S170), a gene frequently rearranged with RET in papillary thyroid carcinomas: functional characterization. Oncogene. 2004;23:109-21.

98. Merolla F, Pentimalli F, Pacelli R, Vecchio G, Fusco A, Grieco M, et al. Involvement of $\mathrm{H} 4(\mathrm{D} 10 \mathrm{S170})$ protein in ATM-dependent response to DNA damage. Oncogene. 2007;26:6167-75.

99. Merolla F, Luise C, Muller MT, Pacelli R, Fusco A, Celetti A. Loss of CCDC6, the first identified RET partner gene, affects PH2AX S139 levels and accelerates mitotic entry upon DNA damage. PLoS One. 2012;7:e36177.

100. Leone V, Mansueto G, Pierantoni GM, Tornincasa M, Merolla F, Cerrato A, et al. CCDC6 represses CREB1 activity by recruiting histone deacetylase 1 and protein phosphatase 1. Oncogene. 2010;29:4341-51.

101. Luise C, Merolla F, Leone V, Paladino S, Sarnataro D, Fusco A, et al. Identification of sumoylation sites in CCDC6, the first identified RET partner gene in papillary thyroid carcinoma, uncovers a mode of regulating CCDC6 function on CREB1 transcriptional activity. PLoS One. 2012;7:e49298.

102. Cerrato A, Merolla F, Morra F, Celetti A. CCDC6: the identity of a protein known to be partner in fusion. Int J Cancer. 2017; Oct 16; [Epub ahead of print]

103. Grieco M, Santoro M, Berlingieri MT, Melillo RM, Donghi R, Bongarzone I, et al. PTC is a novel rearranged form of the ret proto-oncogene and is frequently detected in vivo in human thyroid papillary carcinomas. Cell. 1990;60:557-63.

104. Giannini R, Salvatore G, Monaco C, Sferratore F, Pollina L, Pacini F, et al. Identification of a novel subtype of H4-RET rearrangement in a thyroid papillary carcinoma and lymph node metastasis. Int J Oncol. 2000;16(3):485-9.

105. Elisei R, Romei C, Soldatenko PP, Cosci B, Vorontsova T, Vivaldi A, et al. New breakpoints in both the $\mathrm{H} 4$ and RET genes create a variant of PTC-1 in a post-Chernobyl papillary thyroid carcinoma. Clin Endocrinol. 2000;53:131-6.

106. Drechsler M, Hildebrandt B, Kündgen A, Germing U, Royer-Pokora B. Fusion of H4/D10S170 to PDGFRbeta in a patient with chronic myelomonocytic leukemia and long-term responsiveness to imatinib. Ann Hematol. 2007:86:353-4

107. Wang $Y$, Ding $X$, Wang $S$, Moser CD, Shaleh HM, Mohamed EA, et al. Antitumor effect of FGFR inhibitors on a novel cholangiocarcinoma patient derived xenograft mouse model endogenously expressing an FGFR2-CCDC6 fusion protein. Cancer Lett. 2016;380:163-73.

108. Choi YL, Soda M, Yamashita Y, Ueno T, Takashima J, Nakajima T, et al. EML4ALK mutations in lung cancer that confer resistance to ALK inhibitors. N Engl J Med. 2010;363:1734-9.

109. Takeuchi K, Choi YL, Soda M, Inamura K, Togashi Y, Hatano S, et al. Multiplex reverse transcription-PCR screening for EML4-ALK fusion transcripts. Clin Cancer Res. 2008;14:6618-24

110. Sanders HR, Li HR, Bruey JM, Scheerle JA, Meloni-Ehrig AM, Kelly JC, et al. Exon scanning by reverse transcriptase-polymerase chain reaction for detection of known and novel EML4-ALK fusion variants in non-small cell lung cancer. Cancer Genet. 2011;204:45-52.

111. Sabir SR, Yeoh S, Jackson G, Bayliss R. EML4-ALK variants: biological and molecular properties, and the implications for patients. Cancers (Basel). 2017 Sep 5;9(9). pii: E118. https://doi.org/10.3390/cancers9090118.

112. Heuckmann JM, Balke-Want H, Malchers F, Peifer M, Sos ML, Koker M, et al. Differential protein stability and ALK inhibitor sensitivity of EML4-ALK fusion variants. Clin Cancer Res. 2012;18:4682-90.

113. Woo CG, Seo S, Kim SW, Jang SJ, Park KS, Song JY, et al. Differential protein stability and clinical responses of EML4-ALK fusion variants to various ALK inhibitors in advanced ALK-rearranged non-small cell lung cancer. Ann Oncol. 2017;28(4):791-7. https://doi.org/10.1093/annonc/mdw693.

114. Morra F, Luise C, Merolla F, Poser I, Visconti R, llardi G, et al. FBXW7 and USP7 regulate CCDC6 turnover during the cell cycle and affect cancer drugs susceptibility in NSCLC. Oncotarget. 2015;6:12697-709.

115. Malapelle U, Morra F, llardi G, Visconti R, Merolla F, Cerrato A, et al. USP7 inhibitors, downregulating CCDC6, sensitize lung neuroendocrine cancer cells to PARP-inhibitor drugs. Lung Cancer. 2017;107:41-9.

116. Morra F, Merolla F, Napolitano V, llardi G, Miro C, Paladino S, et al. The combined effect of USP7 inhibitors and PARP inhibitors in hormone- sensitive and castration-resistant prostate cancer cells. Oncotarget. 2017:8: 31815-31829. Oncotarget. 2017;8(19):31815-31829. https://doi.org/10.18632/ oncotarget.16463.

117. Mofers A, Pellegrini P, Linder S, D'Arcy P. Proteasome-associated deubiquitinases and cancer. Cancer Metastasis Rev. 2017;36:635-53.

118. Vaishnavi A, Schubert L, Rix U, Marek LA, Le AT, Keysar SB, et al. EGFR mediates responses to small-molecule drugs targeting oncogenic fusion kinases. Cancer Res. 2017;77:3551-63.

119. Leone V, Langella C, Esposito F, Arra C, Palma G, Rea D, et al. Ccdc6 knockin mice develop thyroid hyperplasia associated to an enhanced CREB1 activity. Oncotarget. 2015:6:15628-38.

120. Aguiari G, Bizzarri F, Bonon A, Mangolini A, Magri E, Pedriali M, et al. Polycystin- 1 regulates amphiregulin expression through CREB and AP1 signalling: implications in ADPKD cell proliferation. J Mol Med. 2012:90:1267-82.

121. Yonesaka K, Zejnullahu K, Lindeman N, Homes AJ, Jackman DM, Zhao F, et al. Autocrine production of amphiregulin predicts sensitivity to both gefitinib and cetuximab in EGFR wild-type cancers. Clin Cancer Res. 2008;14:6963-73.

122. Chen Z, Chen J, Gu Y, Hu C, Li JL, Lin S, et al. Aberrantly activated AREGEGFR signaling is required for the growth and survival of CRTC1-MAML2 fusion-positive mucoepidermoid carcinoma cells. Oncogene. 2014;33:3869-77.

123. Chang $H$, Sung JH, Moon SU, Kim HS, Kim JW, Lee JS. EGF induced RET inhibitor resistance in CCDC6-RET lung cancer cells. Yonsei Med J. 2017;58:9-18.

124. Klempner SJ, Bazhenova LA, Braiteh FS, Nikolinakos PG, Gowen K Cervantes CM, et al. Emergence of RET rearrangement co-existing with activated EGFR mutation in EGFR-mutated NSCLC patients who had progressed on first- or second-generation EGFR TKI. Lung Cancer. 2015;89:357-9.

125. Wang F, Wang S, Wang Z, Duan J, An T, Zhao J, et al. Phosphorylated EGFR expression may predict outcome of EGFR- TKls therapy for the advanced NSCLC patients with wild-type EGFR. J Exp Clin Cancer Res. 2012;31:65.

126. Barbi S, Cataldo I, De Manzoni G, Bersani S, Lamba S, Mattuzzi S, et al. The analysis of PIK3CA mutations in gastric carcinoma and metanalysis of literature suggest that exon-selectivity is a signature of cancer type. J Exp Clin Cancer Res. 2010;29:32

127. Visconti R, Della Monica R, Grieco D. Cell cycle checkpoint in cancer: a therapeutically targetable double-edged sword. J Exp Clin Cancer Res. 2016:35:153

128. Della Monica R, Visconti R, Cervone N, Serpico AF, Grieco D. Fcp1 phosphatase controls Greatwall kinase to promote PP2A-B55 activation and mitotic progression. elife. 2015;4:e10399.

129. Visconti R, Della Monica R, Palazzo L, D'Alessio F, Raia M, Improta S, et al. The Fcp1-Wee1-Cdk1 axis affects spindle assembly checkpoint robustness and sensitivity to antimicrotubule cancer drugs. Cell Death Differ. 2015:22:1551-60

130. Morra F, Luise C, Visconti R, Staibano S, Merolla F, llardi G, et al. New therapeutic perspectives in CCDC6 deficient lung cancer cells. Int J Cancer. 2015;136:2146-57.

131. Visconti R, Morra F, Guggino G, Celetti A. The between now and then of lung cancer chemotherapy and immunotherapy. Int J Mol Sci. 2017;18(7)

132. Cerrato A, Morra F, Celetti A. Use of poly ADP-ribose polymerase [PARP] inhibitors in cancer cells bearing DDR defects: the rationale for their inclusion in the clinic. J Exp Clin Cancer Res. 2016;35:179.

133. Staibano S, llardi G, Leone V, Luise C, Merolla F, Esposito F, et al. Critical role of CCDC6 in the neoplastic growth of testicular germ cell tumors. BMC Cancer. 2013:13:433.

134. Rossi M, Colecchia D, llardi G, Acunzo M, Nigita G, Sasdelli F, et al. MAPK15 upregulation promotes cell proliferation and prevents DNA damage in male germ cell tumors. Oncotarget. 2016;7:20981-98.

135. Mascolo M, Ilardi G, Romano MF, Celetti A, Siano M, Romano S, et al. Overexpression of chromatin assembly factor-1 p60, poly(ADP-ribose) polymerase 1 and nestin predicts metastasizing behaviour of oral cancer. Histopathology. 2012;61:1089-105. 